\title{
Effects of copper on the leaf morpho-anatomy of Rhizophora mucronata: Implications for mangrove ecosystem restoration
}

\author{
KERSTIN LEI DJ. PEREZ", MARILYN O. QUIMADO, LERMA SJ. MALDIA, CRUSTY E. TINIO, \\ JONATHAN O. HERNANDEZ, MARILYN S. COMBALICER, ${ }^{, \vee}$ \\ Department of Forest Biological Sciences, College of Forestry and Natural Resources, University of the Philippines Los Baños. \\ College, Laguna 4031 Philippines, "email: kdperez1@up.edu.ph, "v mscombalicer@up.edu.ph.
}

Manuscript received: 27 January 2021. Revision accepted: 28 March 2021.

\begin{abstract}
Perez KLDJ, Quimado MO, Maldia MLSJ, Tinio CE, Hernandez JO, Combalicer MS. 2021. Effects of copper on the leaf morpho-anatomy of Rhizophora mucronata: Implications for mangrove ecosystem restoration. Biodiversitas 22: 2058-2065. Mangrove is one of the important yet threatened ecosystems in the Philippines. One of the reported causes of its destruction is heavy-metal pollution. Forest restoration managers recommend species that exhibit functional and adaptive traits in their leaf morpho-anatomy to restore degraded mangrove ecosystem's ecological integrity. In this study, we examined the morphological and leaf anatomical characteristics of Rhizophora mисronata Lam. growing in mangrove sites in Mamburao, Occidental Mindoro, Philippines with various concentrations of copper element in the soil were to determine the species adaptation in copper exposed soil and its potential for mangrove ecosystem restoration. Leaf area was measured and leaf anatomy characteristics were determined through histological paraffin technique. The average leaf area of $R$. mucronata in the copper-rich site was relatively smaller than in site with considerably less copper concentration. Further, in the copper-rich site anatomical characteristics (e.g. thicker cuticular, upper epidermis, and hypodermal layers, thin mesophyll layers and vascular bundle, smaller and fewer xylary elements, and larger salt secretion cells indicate functional and adaptive traits. These structures may help $R$. mucronata tolerate the high concentration of heavy metals in the plant body and soil, suggesting its potential for mangrove ecosystem restoration especially in copper-polluted sites in the Philippines.
\end{abstract}

Keywords: Heavy-metals, leaf area, mesophyll, salt secretion cell, vascular bundle

\section{INTRODUCTION}

Mangroves are valuable components of the coastal environment, playing an important role in maintaining an ecological balance within terrestrial and marine ecosystems (Lee et al. 2014), protecting the coast from the damage of recurrent storms and rising sea level (Polidoro et al. 2010). Paz-Alberto et al. (2015) discussed also the mangrove diversity and phytoremediation potential. However, despite its ecological and socio-economic values, several mangrove areas have become wastelands. Many of the wastes are of anthropogenic origin and metallic in nature (Peters et al. 1997) due to rapid industrialization and urbanization (Yan et al. 2017). Increase in heavy metal (HM) pollution and degradation of mangroves, associated with global change, has been reported in many countries (Tam 2006; Zhang et al. 2016; Daza et al. 2020).

Heavy metals, i.e. nickel (Ni), zinc ( $\mathrm{Zn})$, cadmium $(\mathrm{Cd})$, and copper $(\mathrm{Cu})$, are widely known as some of the most toxic contaminants, causing a broad range of physiological abnormalities in plants (Amari et al. 2017; Ali et al. 2019; Samara et al. 2020). Specifically, $\mathrm{Cu}$ is one of the most abundant pollutants which is of extreme ecotoxicological concern within coastal and marine ecosystems (MacFarlane and Burchett 2002). Excessive concentrations and uptake of $\mathrm{Cu}$ can cause cellular damage to plants, leading to necrosis, chlorosis, drastic decrease in photosynthetic activities, and increased mortality (Naidoo and Chirkoot 2004).

The growth and survival of mangrove plants are generally related to their adaptability to high-stress habitats (He et al. 2013). Thus, mangroves exhibit a range of morpho-anatomical responses to extreme environmental conditions (Wang et al. 2011). Moreover, several mangrove species are able to eliminate or alleviate the effects of toxic heavy metal through certain adaptive traits, such as the presence of salt glands, excretory glandular trichomes, and other epidermal indumenta (Drennan and Pammenter 1982; Tan et al. 2013). Among the mangrove species that have long been characterized by having specialized glands is Rhizophora mucronata Lam (Atkinson et al. 1967).

Rhizophora mucronata (Rhizophoraceae), locally known as 'Bakauan babae', is a native mangrove species in the Philippines. It is widespread in the Indo-Malayan region (Setyawan et al. 2014) and highly preferred species for mangrove restoration (Duke et al. 2010). Due to its high capacity to act as carbon sink, its wood is characterized by high calorific content that is highly preferred for fuelwood and charcoal making. The current $R$. mucronata population is reported to be decreasing. However, there is a lack of conservation measures specific to this species (Duke et al. 2010).

Rhizophora mucronata has unique biological mechanisms and strong adaptive ability towards the presence of heavy metal (Macfarlane et al. 2007), which 
are commonly translocated and largely stored within the roots and leaves (MacFarlane et al. 2003). However, very little is known about the morphological and anatomical mechanisms of $R$. mucronata under heavy metal conditions particularly $\mathrm{Cu}$, an essential micronutrient for plant growth. Investigating these mechanisms could lead to a better understanding of the role of Philippine mangroves in phytoremediation contaminated wetlands, thereby providing important insights into mangrove ecosystem restoration. Thus, the present study aimed to investigate the functional and adaptive traits in the leaf morphoanatomical characteristics of $R$. mucronata planted in copper-rich and in mangrove sites with considerably less $\mathrm{Cu}$ to provide implications for mangrove ecosystem restoration.

\section{MATERIALS AND METHODS}

\section{Study site}

Leaf samples were collected from the two selected Barangays, Fatima and Tayamaan, in Mamburao, Occidental Mindoro, Philippines (13.196672 N, 120.653397 E and 13.239206 N, 120.526942 E; elevation 5 and $3 \mathrm{~m}$ a.s.1., respectively) with distinct mangrove formations. Mamburao, Occidental Mindoro lies on the western part of the island of Mindoro, located south of the province of Batangas in Southern Luzon and Northwest of the Visayas (Figure 1). Occidental Mindoro has an estimated total of 1,594 ha by the Forest Management Bureau (FMB) in 2010. In 2011, an estimate of 1,842.93 ha based on the Landsat imagery was published in Long and Giri (2011), and in 2015 there was 1,386 ha based on 2015 Landsat Imagery (Songcuan et al. 2015). In the coastal resource map provided by the Department of Environment and Natural Resources-National Mapping and Resource Information Authority (DENR-NAMRIA), there is 16 ha of mangrove forest in the Municipality of Mamburao. Vela Cruz and Pangilinan (2015) report on the state of mangroves in Southern Luzon specifically attributed the decline of mangroves in the province for various reasons such as conversion into aquaculture areas, reclamation for agriculture and settlements, cutting for firewood and housing materials, as well as due to sedimentation.

Occidental Mindoro is also rich in mineral reserves (Mines and Geosciences Bureau Region-Department of Environment and Natural Resources Region 4B or MIMAROPA, 2009 as cited in the MIMAROPA Regional Development Plan 2011-2016). Within the region, approximately $58 \%(59,281 \mathrm{ha})$ covered by the large-scale mining tenements are situated on the island of Mindoro. In the mining tenement control map for Occidental Mindoro published by the MGB-DENR-R4B (http://www.mgb.gov.ph), several portions of the province, including the Municipality of Mamburao have existing or approved application for various minerals such as iron $(\mathrm{Fe})$, gold $(\mathrm{Au})$, and $\mathrm{Cu}$ explorations. The two Barangays in this study are situated in potentially gold and/or copper-rich soil in the mining tenement control map.

\section{Leaf sample and soil collection}

In each site, we established a $25 \mathrm{~m} \times 50 \mathrm{~m}$ plot. Using randomization, we selected five (5)-standing trees of $R$. mucronata in each plot. In each tree, three fully matured leaf samples were collected at the top, middle, and bottom portions of the tree based on sun exposure. Leaf samples were cut $\left(1 \mathrm{~cm}^{2}\right)$ and stored in microcentrifuge tube with fixative solution prior to transport from the site to the Microtechnique Laboratory of the Department of Forest Biological Sciences, College of Forestry and Natural Resources, University of the Philippines Los Baños (DFBS-CFNR-UPLB).

Composite soil sampling was conducted in each plot with a depth of $1.3 \mathrm{~cm}$. The samples were analyzed for the presence of HM. Diethylenetriamine penta acetic acid (DTPA) was used to extract solution and samples were analyzed using the atomic absorption spectrophotometer at the College of Agriculture and Food Science Agricultural Systems Institute (CAFS-ASI) Analytical Services Laboratory, UPLB.

\section{Morphological characteristics}

A total of fifteen (15) leaf specimens were collected. The leaf traits were measured and observed at each site. The leaf area was measured with the aid of the ruler in $\mathrm{cm}$ and grid method in $\mathrm{cm}^{2}$, following the modified procedure and equation in $\mathrm{Li}$ et al. (2008). The root system of the species was documented and described based on the existing literature about the root types of mangroves (Kitaya et al. 2002; Comley and McGuiness 2005; Clough 2013; Ong et al. 2013).

\section{Anatomical characteristics}

Freshly collected leaf samples (five samples per individual tree) of $R$. mucronata were transversely cut near the apex portion, including the midrib measuring $1 \mathrm{~cm}^{2}$. Samples were fixed in a specialized FAA (Formalin Acetic Acid) solution for one month. The leaf samples underwent the process of dehydration in a series of alcohol concentrations (i.e., 50-100\%) and infiltration through wax changes (Johansen 1940). To examine the anatomical leaf characteristics, samples were viewed under a high-powered microscope. Each anatomical parameter was measured and documented using OPTIKA microscope and software. The typologies presented in Haupt (1953), Fahn (1967), Bell (2008), and Shipunov (2020) were followed to describe the anatomy of the plant.

\section{Statistical analysis}

Descriptive statistics and T-test (two-sample assuming unequal-variances) were used to test for significance of the mean differences in terms of morphological and anatomical characteristics of $R$. mucronata. Analysis was performed using Excel Analysis ToolPak. 


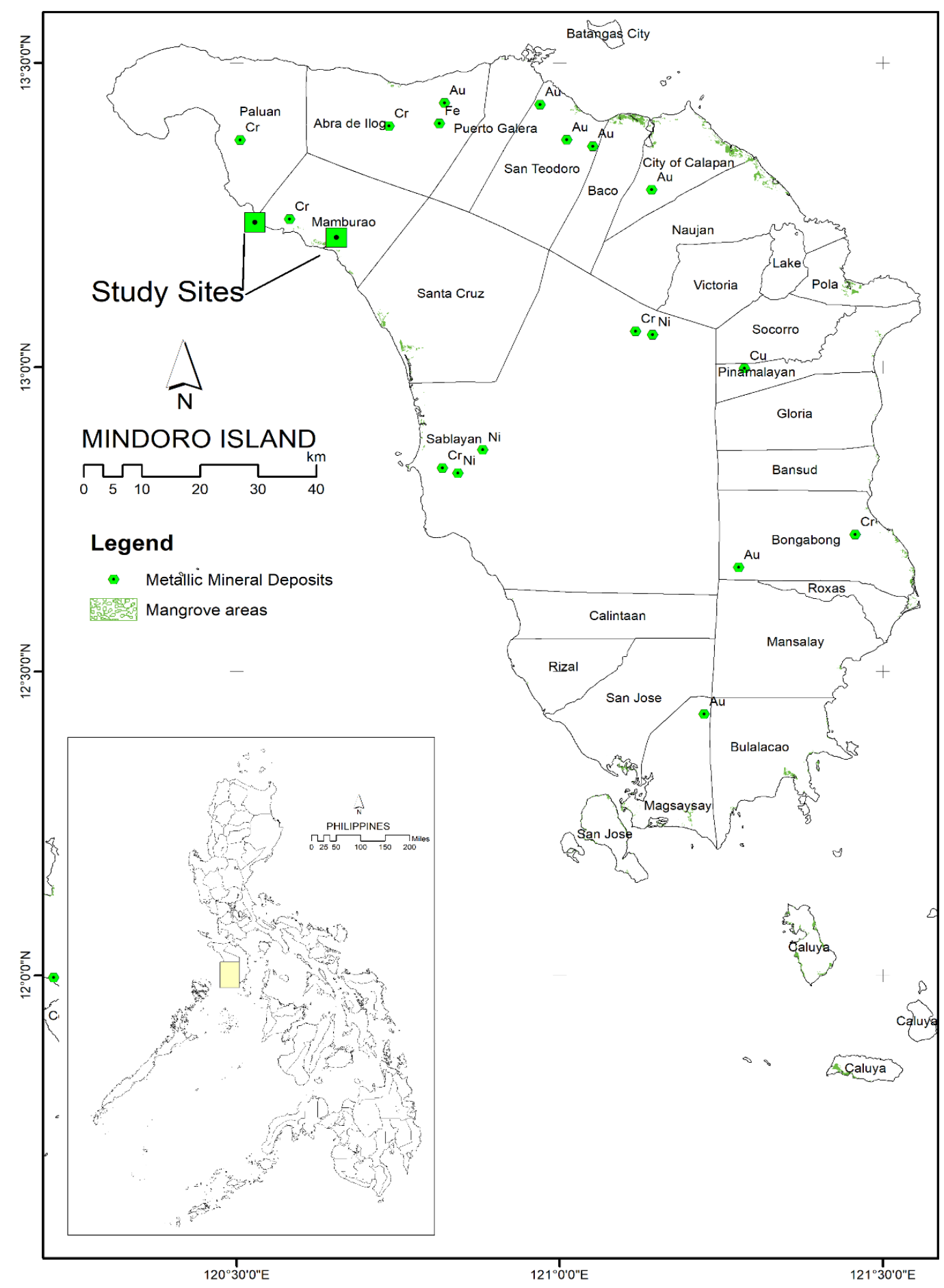

Figure 1. Location of the study sites in Mamburao, Occidental Mindoro, Philippines

\section{RESULTS AND DISCUSSION}

\section{Soil copper content in mangrove study sites}

Based on the soil analysis for heavy metals, in the mangrove stand in Barangay Fatima soil contained a small amount of $\mathrm{Cu}(3 \mathrm{ppm})$, while in Barangay Tayamaan the soil contained a remarkable amount of $\mathrm{Cu}(252 \mathrm{ppm})$. Thus, the Tayamaan is considered a copper-rich mangrove area in this study.

\section{Morphological features}

The leaf area of $R$. mucronata was significantly smaller in the copper-rich mangrove site in Barangay Tayamaan compared to the less $\mathrm{Cu}$ site in Barangay Fatima $(P=0.00011)$. The average leaf area of $R$. mucronata in Barangay Tayamaan was $28.39 \pm 0.67 \mathrm{~cm}^{2}$, while in Barangay Fatima the leaf area was $32.12 \pm 0.48 \mathrm{~cm}^{2}$. The leaf of $R$. mucronata is characterized by having a leathery with noticeable midrib, medium size, ovate shape, elliptical oblong lamina, and 
acute apex.

\section{Anatomical features}

Table 1 shows the average measurements of various leaf anatomical characters of $R$. mucronata in the two mangrove sites. The average thicknesses of the cuticular, epidermal layers, and hypodermis of leaves in the copperrich mangrove site in Barangay Tayamaan were all consistently higher than those in Barangay Fatima (Figure 2.A-B). However, a significant difference was only observed in the epidermal layers only. The hypodermis presence is common in mangroves especially in species without salt glands. The hypodermis is characterized by large and water-filled cells. In contrast, the average thickness of the mesophyll (palisade and spongy) and vascular bundles was consistently smaller in Barangay Tayamaan than in Barangay Fatima (Figure 2.C-F), which were generally statistically different. In $R$. mucronata, the salts are secreted through the specialized gland in the lower epidermis called cork warts. Salt excretion cells were also found considerably larger in Barangay Tayamaan (Figure 2.G-H).

Table 1. Average thicknesses $(\mu \mathrm{m})$ of the leaf anatomical features of Rhizophora mucronata in Barangay Fatima and Barangay Tayamaan, Mamburao, Occidental Mindoro $(n=15)$

\begin{tabular}{lccc}
\hline Parameter & Barangay Fatima & Barangay Tayamaan & $\boldsymbol{P}$ value \\
\hline Upper cuticle & $16.00 \pm 1.31$ & $20.67 \pm 2.06$ & 0.0662 \\
Upper epidermis & $20.00 \pm 2.18$ & $33.33 \pm 1.26$ & 0.0001 \\
Lower epidermis & $14.00 \pm 1.31$ & $32.67 \pm 2.06$ & 0.0000 \\
Lower cuticle & $12.00 \pm 1.07$ & $15.33 \pm 1.33$ & 0.0613 \\
Hypodermis & $170.00 \pm 9.05$ & $202.67 \pm 8.48$ & 0.0136 \\
Vascular bundle & $360.67 \pm 8.59$ & $292.67 \pm 8.19$ & 0.0000 \\
Palisade mesophyll & $180.67 \pm 9.23$ & $85.33 \pm 5.24$ & 0.0000 \\
Spongy mesophyll & $351.30 \pm 17.30$ & $338.67 \pm 9.15$ & 0.5248 \\
Salt excretion cell & $234.00 \pm 13.00$ & $567.30 \pm 30.50$ & 0.0000 \\
\hline
\end{tabular}

Note: Mean + the standard error. T-test result of two-samples assuming unequal variances $\alpha=0.05$.
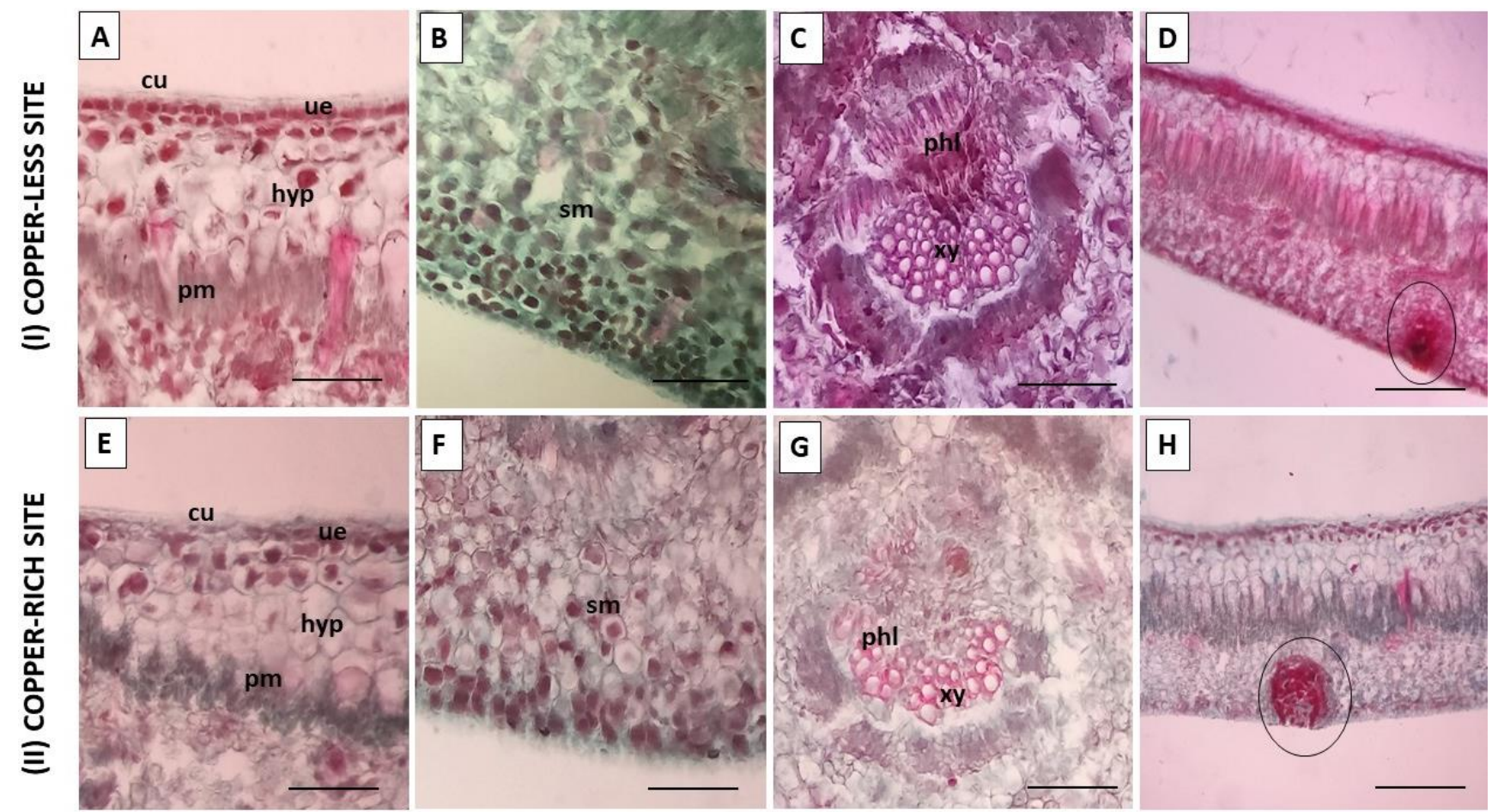

Figure 2. Leaf cross-section of Rhizophora mucronata in (I) copper-less site and (II) copper-rich site showing the cuticle (cu), upper epidermis (ue), hypodermis (hyp), and palisade mesophyll (pm) (I-A, II-E); the spongy mesophyll (sm) (I-B, II-F); vascular bundle (phl, phloem; xy, xylem) (I-C, II-G); and salt excretion cell (I-D, II-H), respectively. Bar represents $100 \mu \mathrm{m}$ 


\section{Discussion}

Morphological features

As leaves are very important in photosynthesis, respiration, and other plant functions, a decrease in the leaf area will also decrease the number of stomata. This prevents carbon dioxide $\left(\mathrm{CO}_{2}\right)$ from entering the cells, which is a component for photosynthesis, and it prevents the diffusion of water during transpiration. Reduction in leaf area growth can also result in a reduced light interception and smaller epidermal space, which can impair photosynthesis rate and plant's metabolic processes (Weraduwage et al. 2016; Liu et al. 2020). These physiological responses are likely to explain the significant reduction in the mean leaf area of $R$. mucronata in the copper-rich mangrove in Barangay Tayamaan compared to that in Barangay Fatima. A study showed that heavy metal stress, including $\mathrm{Ni}, \mathrm{Cu}, \mathrm{Co}$, and $\mathrm{Cr}$, resulted in a reduction in leaf-specific conductivity, which is the ratio of stem conductivity to leaf area (de Silva et al. 2012).

Due to anthropogenic factors and extreme urbanization rates, mangroves are threatened by environmental conditions that are one of the major causes in their decline (Carugati et al. 2018; Ward et al. 2016). With these conditions, the morphological changes in the mangroves as affected by heavy metals may not be readily noticeable but the alteration in the structure of mangroves can be directly observed in anatomical characteristics of the leaf as observed in this study.

\section{Anatomical features}

Dermal layer. Heavy metal stress in mangrove plants is characterized by the shortage in water availability in the tissues because the ion concentration of metals increases in the tissues, thus, mangroves should equip themselves with thicker cuticle and epidermis in order to minimize the loss of water in their tissues (Lucena et al. 2011; Sereneski-de Lima et al. 2013; Surya and Hari 2017). These cuticular and upper epidermal responses to harsh conditions, specifically heavy metal stress, are evident in the thicker cuticular and upper epidermal layers observed in $R$. mucronata in the copper-rich mangrove site in this study. A review of water relations in plants subjected to heavy metal stress illustrated that a decrease in leaf thickness reduces the rate of transpiration (Rucińska-Sobkowiak 2016). Therefore, we could state that the observed thicker cuticular and upper epidermal layers in $R$. mucronata are adaptive mechanisms that could help the species tolerating the effects of heavy metals through osmotic adjustment. Enhanced osmotic adjustment attributed to the accumulation of inorganic compounds was already reported for Avicennia marina (Forssk.) Vierh. (Zhu et al. 2011).

Here we found that the mean thickness of leaf hypodermis in the copper-rich mangrove site in Barangay Tayamaan was significantly higher than those in Barangay Fatima. This result supports the study of Sereneski-de Lima et al. (2013), who reported the presence of hypodermis (also known as sub-epidermal tissue) in three mangrove species. The author further noted that the presence of hypodermis suggests sclerophylly in Rhizophora mangle L. and Avicennia schaueriana Stapf \& Leechm. ex Moldenke.
The presence of hypodermis is common in mangroves especially in species without salt glands. The hypodermis is characterized by large and water-filled cells (Saenger 2002). Thus, the increase in the number of cells and the thickness of hypodermis in copper-rich soil could be an adaptive mechanism of plants in response to metal stress to compensate for the deterioration of chlorophyll structures (Gomes et al. 2011). Further, the thick hypodermis acts as a barrier to lower or limit the translocation of metals to the chlorophyll parenchyma, preventing further damage in the $\mathrm{CO}_{2}$ fixation system. The large water-filled cells stores a significant amount of water to prevent dehydration during transpiration due to environmental stress. It is also reported that the thickness of the hypodermis is positively correlated to the higher degree of stress in Rhizophoraceae species (Clough 2013).

Mesophyll. The present study results showed that in the copper-rich mangrove site, both the palisade and spongy layers appeared to have thinner cells and fewer intercellular spaces, respectively. According to Azmat et al. (2009), the relatively loose arrangement of the spongy layer (observed here in the less $\mathrm{Cu}$ site in Barangay Fatima as shown in Figure 2.I-A) allows the rapid diffusion of carbon dioxide which facilitates the photosynthesis, while the compacted arrangement of the spongy layer (observed here in the copper-rich site in Barangay Tayamaan as shown in Figure 2.II-F) inhibits the rapid diffusion of the carbon dioxide and other gases and affects the photosynthetic capacity of the leaf. Photosynthesis is very sensitive in vascular plants ( $\mathrm{Gu}$ et al. 2002). Heavy metal stress destructs the chloroplast structure, alters the chlorophyll synthesis, and obstructs the enzymatic activities of the Calvin cycle and causes $\mathrm{CO}_{2}$ deficiency (Shi and Cai 2008), thus, reducing the thickness of the mesophyll layers (Srighar et al. 2005). Gomes et al. (2011) showed that plants exposed to metal contamination had decreased photosynthetic rate and the decrease of photosynthetic rate was directly proportional to the level of contamination. Although the photosynthetic rates of $R$. mucronata were not measured in this study, there was a significant reduction in the leaf area and palisade thickness in the copper-rich mangrove site in Barangay Tayamaan. This is an indication that chloroplasts, which largely reside in the palisade, may have been greatly reduced and potentially rendered low photosynthetic rates. MacFarlane and Burchett (2001) found that photopigments in the leaves of A. marina decreased significantly under $\mathrm{Cu}$ and $\mathrm{Zn}$ treatments even at concentrations lower than those inducing visible metal toxicity.

Vascular bundles. The vein or the vascular bundle (Figure 2.I-C, II-G) consists of two vascular tissues, namely xylem and phloem. The xylem functions mainly for the transport of water and other minerals, while the phloem functions mainly for the transport of dissolved sugars. Based on the results, the vascular bundle was thicker with a higher number of xylem vessels in the copper-rich site (Figure 2.II-G) than in the site of relatively less $\mathrm{Cu}$ (Figure 2.I-C). The decrease in vascular bundle thickness and the number of xylem vessels is due to the response of mangroves to salinity (Clough 2013) and a response to 
heavy metals (Sandalio et al. 2001). The hydraulic conductivity of the xylem is also impaired when exposed to stress which inhibits the transfer of sugars and water needed for photosynthesis. Lovelock et al. (2006) also reported that the xylem hydraulic conductivity is decreasing with increasing salinity which implies that the hydraulic conductivity and other functions of the vein are affected by environmental stressors. Further, a review showed that reduction in the size and density of vessels and tracheids in stem caused by metal stress or toxic ions can decelerate the water supply from roots-to-leaf (RucinskaSobkowiak 2016), thereby affecting the photosynthesis and other physiological processes that take place in leaves.

Salt secretion cell. Although increased heavy metal concentration is highly considered to affect the morphophysiological responses in mangroves, the effects of salinity in mangrove species cannot be disregarded. Salinity-induced stress in $R$. mucronata may be acting in tandem with the heavy metal concentration in the plant tissues, affecting the overall metabolic processes in plants. Qiu et al. (2007) reported that an increase in salinity decreases the leaf area and the stomatal conductance of Kandelia candel. In Avicennia marina along the anthropogenically stressed tropical creek in Thane Creek in the Arabian Sea, A. marina in higher salinity showed increased thickness of the hypodermal water storage tissue in the leaf and produced taller salt extruding glands at the lower epidermis but a decreased mesophyll thickness (Borkar et al. 2009). Our results showed that the leaves of $R$. mucronata exhibited salt secretion cells and cork warts, with higher arc length (Figure 2.II-H) than the leaves in the less $\mathrm{Cu}$ site (Figure 2.I-D). Salt secretion cells regulate the internal salt level in the internal structure of mangroves by secreting excess salts through specialized glands (Parida and Jha 2010). The increase in salinity level enhances the size of the salt secretion cells, thus, high amounts of salts and metals can be excreted (Ye et al. 2005).

High concentrations of metals in the tissues of mangrove species including Rhizophora species in high saline and polluted environments have been recorded by various researchers (Macfarlane and Burchett 2000). Generally, the uptake, distribution, and excretion of heavy metals in mangroves are highly affected by salt stress adaptation (Macfarlane and Burchett 2000).

Rhizophora mucronata growing in copper-rich mangrove soil have adapted to this condition through the changes in the leaf morpho-anatomical characteristics. Morphologically, the leaf area of samples growing in copper-rich site decreases as compared to the leaf area growing in soil with considerably less $\mathrm{Cu}$. Anatomically, there is a general increase in the thickness of tissues embedded and adjacent to the epidermis (cuticular layer, epidermis, hypodermis, salt excretion cells) and a general decrease in the thickness of vascular and ground tissues of $R$. mucronata in the copper-rich site.

These alterations in the morpho-anatomical characteristics are suggestive of the adaptive mechanisms of $R$. mucronata and its potential for phytoremediation. Copper-rich site anatomical characteristics of $R$. mucronata indicate functional and adaptive traits that may help the species tolerate the high concentration of heavy metals in the plant body and soil. Therefore, R. mucronata is a potential species for mangrove ecosystem restoration. However, there is a need to completely understand $\mathrm{Cu}$ intake effects in plant tissue system of mangrove species like $R$. mucronata. There is also a need to assess the capacity of the plant tissue to absorb $\mathrm{Cu}$ and the level of $\mathrm{Cu}$ accumulation in plant tissues and organs needs to be examined. Nonetheless, the study results can help in the sustainable management of mangrove ecosystems and thereby contribute to the country's effort to restore degraded mangrove areas in the country.

\section{ACKNOWLEDGEMENTS}

The authors wish to thank the College of Forestry and Natural Resources specifically the Metallophytes Laboratory of the Department of Forest Biological Sciences for the use of chemicals, equipment, and facilities during the experiment. The authors also thank the National Mapping Authority and Resource Information Authority (NAMRIA) for providing the map data for the location of the study sites.

\section{REFERENCES}

Ali H, Khan E, Ilahi I. 2019. Environmental chemistry and ecotoxicology of hazardous heavy metals: Environmental persistence, toxicity, and $\begin{array}{llllll}\text { bioaccumulation. } \mathrm{J} \text { Chem } 2019 & \text { (4): 1-14. DOI: }\end{array}$ 10.1155/2019/6730305.

Alves ES, Giusti PM, Domingos M. 2001. Anatomic studies on Tradescantia hybrid clone 4430 leaves: Changes caused by urban air pollution. Rev Bras Bot 24: 561-566. DOI: 10.1590/S010084042001000500012

Amari T, Ghnaya T, Abdelly C. 2017. Nickel, cadmium and lead phytotoxicity and potential of halophytic plants in heavy metal extraction. S Afr J Bot 111: 99-110. DOI: 10.1016/j.sajb.2017.03.011.

Azmat R, Haider S, Nasreen H, Aziz F, Riaz M. 2009. A viable alternative mechanism in adapting the plants to heavy metal environments. Pak $\mathbf{J}$ Bot 41 (6): 2729-2738.

Bell AD. 2008. Plant Form: An Illustrated Guide to Flowering Plant Morphology. Oxford University Press, London. 393 p.

Borkar MU, Athalye RP, Goldin Q. 2009. Salinity induced changes in the leaf anatomy of the mangrove Avicennia marina along the anthropogenically stressed tropical creek. J Coast Deve 14(3): 191201.

Clough B. 2013. Continuing the Journey Amongst Mangroves. ISME Mangrove Educational Book Series No. 1. International Society for Mangrove Ecosystems (ISME), Okinawa, Japan, and International Tropical Timber Organization (ITTO), Yokohama, Japan.

Comley BWT, McGuinness KA. 2005. Above and below-ground biomass, and allometry of four common Northern Australian mangroves. Austr J Bot 53: 431-436. DOI: 10.1071/BT04162.

Daza DAV, Moreno HS, Portz L, Manzolli RP, Bolivar-Anillo HJ, Anfuso G. 2020. Mangrove forests evolution and threats in the Caribbean Sea of Colombia. Water 12 (1113): DOI: 10.3390/w12041113.

de Silva NDG, Cholewa E, Ryser P. 2012. Effects of combined drought and heavy metal stresses on xylem structure and hydraulic conductivity in red maple (Acer rubrum L.). J Exp Bot 63: 59575966. DOI: $10.1093 / \mathrm{jxb} / \mathrm{ers} 241$.

Drennan P, Pammenter NW. 1982. Physiology of salt excretion in the mangrove Avicennia marina (Forsk.) Vierh. New Phytol 91 (4): 597606. DOI: 10.1111/j.1469-8137.1982.tb03338.x.

Duke N, Kathiresan K, Salmo III SG, Fernando ES, Peras RJ, Sukardjo S, Miyagi T. 2010. Rhizophora mucronata. The IUCN Red List of 
Threatened Species 2010: e.T178825A7618520. DOI: 10.2305/IUCN.UK.2010 2.RLTS.T178825A7618520.en.

Fahn A. 1967. Plant Anatomy. Pergamon Press Ltd., Oxford. 541 p.

Gomes MP, Melo Marques TCLL, Nogueira MOG, de Castro EM, Soares AM. 2011. Ecophysiological and anatomical changes due to uptake and accumulation of heavy metal in Brachiara decumbens. Plant Physiol Biochem 68 (5): 566-573. DOI: 10.1590/S010390162011000500009.

Gu W, Shi GX, Zhang CY, Wang W, Xu QS, Xu N. 2002. Toxic effects of $\mathrm{Hg}, \mathrm{Cd}$, and $\mathrm{Cu}$ on photosynthetic systems and protective enzyme systems of Potamogeton crispus. J Plant Physiol Mol Biol 28 (1): 6974.

Haupt AW. 1953. Plant Morphology. McGraw-Hill, University of Michigan, USA. 464 p. DOI: 10.5962/bhl.title.5660.

Johansen DA. 1940. Plant Microtechnique. Mc Graw-Hill, New York.

Lee SY, Primavera JH, Dahdouh-Guebas F, McKee KL, Bosire JO, Cannicci S, Diele K, Froamrd F, Koedam N, Marchand C, Mendelssohn IA, Mukjerhee N, Record S. 2014. Ecological role and services of tropical mangrove ecosystems: A reassessment. Glob Ecol Biogeogr 23: 726-743. DOI: 10.1111/geb.12155.

Li Z, Ji C, Liu J. 2008. Leaf area calculating based on digital image. In: Li $\mathrm{D}$, Zhao C (eds). Computer and Computing Technologies in Agriculture II, Vol. 2. The Second IFIP International Conference on Computer and Computing Technologies in Agriculture (CCTA2008), Beijing, 18-20 October 2008. [China]

Liu YY, Zhu Y, Wickremasinghe H, Bergen PJ, Lu J, Zhu XQ, Azad M, Nang SC, Han ML, Lei T, Li J, Liu JL. 2020. Metabolic perturbations caused by the over-expression of mcr-1 in Escherichia coli. Front Microbiol 11:588658. DOI: 10.3389/fmicb.2020.588658.

Long JB, Giri C. 2011. Mapping the Philippines' mangrove forests using Landsat imagery. Sensors 11 (3): 2972-2981. DOI: 10.3390/s110302972.

Lovelock CE, Ball MC, Feller IC, Engelbrecht BMJ, Ewe ML. 2006. Variation in hydraulic conductivity of mangroves: Influence of species salinity, and nitrogen and phosphorus availability. Physio Plant 127: 457-464. DOI: 10.1111/j.1399-3054.2006.00723.x.

Lucena I, Maciel VEDO, da Silva JB, Galvincio JD, Pimentel RMdM. 2011. Leaf structure of mangrove species to understand the spectral responses. J Hyperspectral Rem Sensing 2: 19-31. DOI: 10.5935/2237-2202.20110002.

MacFarlane GR, Burchett MD. 2000. Cellular distribution of $\mathrm{Cu}, \mathrm{Pb}$ and $\mathrm{Zn}$ in the Grey Mangrove Avicennia marina (Forsk.) Vierh. Aquat Bot 68: 45-59. DOI: 10.1016/S0304-3770(00)00105-4.

MacFarlane GR, Burchett MD. 2001. Photosynthetic pigments and peroxidase activity as indicators of heavy metal stress in the Grey Mangrove Avicennia marina (Forsk.) Veirh Mar Pollut Bull 42: 233240. DOI: $10.1016 / \mathrm{S} 0025-326 \mathrm{X}(00) 00147-8$.

MacFarlane GR, Burchett MD. 2002. Toxicity, growth and accumulation relationships of copper, lead and zinc in the Grey Mangrove Avicennia marina (Forsk.) Vierh. Mar Environ Res 54: 65-84. DOI: 10.1016/S0141-1136(02)00095-8.

MacFarlane GR, Pulkownik A, Burchett M.D. 2003. Accumulation and distribution of heavy metals in the Grey Mangrove, Avicennia marina (Forsk.) Vierh: Biological indication potential. Environ Pollut 123: 139-151. DOI: 10.1016/S0269-7491(02)00342-1.

MacFarlane GR, Koller CE, Blomberg SP. 2007. Accumulation and partitioning of heavy metals in mangroves: A synthesis of field-based studies. Chemosphere 69: 1454-1464. DOI: 10.1016/j.chemosphere.2007.04.059.

MIMAROPA Regional Development Plan 2011-2016. MIMAROPA Regional Office. National Economic and Development Authority.

Naidoo G, Chirkoot D. 2004. The effects of coal dust on photosynthetic performance of the mangrove, Avicenna marina in Richards Bay, South Africa. Environ Poll 127 (3): 359-366. DOI: 10.1016/j.envpol.2003.08.018.

Ong JE, Gong WK. 2013. Structure, Function and Management of Mangrove Ecosystems. ISME Mangrove Educational Book Series No. 2. International Society for Mangrove Ecosystems (ISME), Okinawa, Japan, and International Tropical Timber Organization (ITTO), Yokohama, Japan.

Parida AK, Jha B. 2010. Salt tolerance mechanisms in mangrove: A review. Trees 24: 199-217. DOI: 10.1007/s00468-010-0417-x.

Paz-Alberto AM, Vizmonte JLD, Sigua GC. 2015. Diversity and phytoremediation potential of mangroves for copper contaminated sediments in Subic Bay, Philippines. IJPAES 5 (4): 50-59.
Peters EC, Gassman NJ, Firman JC, Richmond RH, Power EA. 1997. Ecotoxicology of tropical marine ecosystems. Environ Toxicol Chem 16: 12-40. DOI: 10.1002/etc.5620160103.

Polidoro BA, Carpenter KE, Collins L, Duke NC, Ellison AM, Ellison JC, Farnsworth EJ, Fernando ES, Kathiresan K, Koedam NE, Livingstone SR, Miyagi T, Moore GE, Nam VN, Ong JE, Primavera JH, Salmo III SG, Sanciangco JC, Sukardjo S, Wang Y, Yong JWH. 2010. The loss of species: Mangrove extinction risk and geographic areas of global $\begin{array}{lllll}\text { concern. PLoS ONE 5(4): } & \text { e10095. DOI: }\end{array}$ 10.1371/journal.pone.0010095.

Qiu DL, Lin P, Guo SZ. 2007. Effects of salinity on leaf characteristics and $\mathrm{CO} 2 / \mathrm{H} 2 \mathrm{O}$ exchange of Kandelia candel (L.) Druce seedlings. J For Sci 53 (1): 13-19. DOI: 10.17221/2081-JFS.

Rucińska-Sobkowiak R. 2016. Water relations in plants subjected to heavy metal stresses. Acta Physiol Plant 38 (257): 1-13. DOI: 10.1007/s11738-016-2277-5.

Saenger P. 2002. Mangrove Ecology, Silviculture and Conservation. Kluwer Academic Publishers Springer, Netherlands. 360 p. DOI: 10.1007/978-94-015-9962-7.

Sandalio LM, Dalurzo HC, Gómes M, Romero-Puertas MC, Del Rio LA. 2001. Cadmium-induced changes in the growth and oxidative metabolism of pea plants. J Exp Bot 52: 2115-2126. DOI: 10.1093/jexbot/52.364.2115.

Samara F, Solovieva N, Ghalayini T, Nasrallah ZA, Saburova M. 2020. Assessment of the environmental status of the mangrove ecosystem in the United Arab Emirates. Water 12: 1623. DOI: 10.3390/w12061623.

Sereneski-de Lima C, Torres-Boeger MR, Larcer-de Carvalho L, Pelozzo A, Soffiatti P. 2013. Sclerophylly in mangrove tree species from South Brazil. Rev Mex Biodivers 84 (4): 1159-1166. DOI: 10.7550/rmb.32149.

Setyawan AD, Ulumuddin YI, Ragavan P. 2014. Mangrove hybrid of Rhizophora and its parental species in Indo-Malayan region. Nusantara Biosci 6: 69-81. DOI: 10.13057/nusbiosci/n060111.

Shi GR, Cai QS. 2008. Photosynthetic and anatomic responses of peanut leaves to cadmium stress. Photosynthetica 46 (4): 627-630. DOI: 10.1007/s11099-008-0107-8.

Shipunov A. 2020. Introduction to Botany. Minot State University, North Dakota, USA.

Songcuan AJG, Baloloy AB, Blanco AC, David LT, Go GA, Cadalzo IE, Estabillo MS, Quides RR, Tamondong A. 2015. Mangrove forest extent mapping in Southwestern Luzon using 2015 Landsat Imagery. In: Salmo III SG, Favis AMT, Ting MNS, Lim ABU (eds). State of the Mangrove Summit: Southern Luzon Proceedings. Ateneo de Manila University, Loyola Heights, Quezon City, 1-2 October 2015. [Philippines] DOI: 10.13185/i241.

Srighar BBM, Diehl SV, Han FX, Monts DL, Su Y. 2005. Anatomical changes due to uptake and accumulation of $\mathrm{Zn}$ and $\mathrm{Cd}$ in Indian mustard (Brassica juncea). Environ Exp Bot 54: 131-141. DOI: 10.1016/j.envexpbot.2004.06.011.

Surya S, Hari N. 2017. Leaf anatomical adaptation of some true mangrove species in Kerala. Int J Pharm Sci Res 2 (3): 11-14.

Tam NFY. 2006. Pollution studies on mangroves in Hongkong and mainland China. In: Wolanski E (eds). The Environment in Asia Pacific Harbours. Springer, Dordrecht. DOI: 10.1007/1-4020-3655$8 \_11$.

Tan WK, Lin QS, Lim TM Kumar P, Loh CS. 2013. Dynamic secretion changes in the salt glands of the mangrove tree species Avicennia officinalis in response to a changing saline environment. Plant Cell Environ 36: 1410-1422. DOI: 10.1111/pce.12068.

Vela Cruz E, Pangilinan MJ. 2015. State of mangroves in Occidental Mindoro. In: Salmo III SG, Favis AMT, Ting MNS, Lim ABU (eds). State of the Mangrove Summit: Southern Luzon Proceedings. Ateneo de Manila University, Loyola Heights, Quezon City, 1-2 October 2015. [Philippines]

Wang WQ, You SY, Wang YB, Huang L, Wang M. 2011. Influence of frost on nutrient resorption during leaf senescence in a mangrove at its latitudinal limit of distribution. Plant Soil 342: 105-115. DOI: 10.1007/s11104-010-0672-z.

Weraduwage SM, Kim SJ, Renna L, Anozie FC, Sharkey TD, Brandizzi F. 2016. Pectin methyl esterification impacts the relationship between photosynthesis and plant growth. Plant Physiol 171: 833-848. DOI: 10.1104/pp.16.00173.

Yan ZZ, Sun XL, Xu Y, Zhang QQ, Li XZ. 2017. Accumulation and tolerance of mangroves to heavy metals: A review. Curr Pollut Rep 3: 302-317. DOI: 10.1007/s40726-017-0066-4. 
Ye Y, Fung-Yee N, Lu CY, Wong YS. 2005. Effects of salinity on germination, seedling growth and physiology of three salt-secreting mangrove species. Aqua Bot 83: 193-205. DOI: 10.1016/j.aquabot.2005.06.006.

Zhang K, Thapa B, Ross M, Gann D. 2016. Remote sensing of seasonal changes and disturbances in mangrove forest: A case study from South Florida. Ecosphere 7 (6): e01366. DOI: 10.1002/ecs2.1366.
Zhu Z, Zhang RF, Liu TW, Zheng HL. 2011. Solute accumulation and osmotic adjustment characteristics of the mangrove Avicennia marina under NaCl-induced salinity stress. Bot Mar 54: 335-341. DOI: 10.1515/Bot.2011.035. 